\title{
PENDIDIKAN YANG AMAN \\ PADA MASA PANDEMI COVID-19
}

\author{
Arif Wicaksono $^{1}$, Arina Nurfianti ${ }^{2}$ \\ ${ }^{1}$ Program Studi Kedokteran, Universitas Tanjungpura, Pontianak \\ ${ }^{2}$ Program Studi Keperawatan, Universitas Tanjungpura, Pontianak \\ E-mail: $\underline{\text { drarifwicaksono@gmail.com }}$
}

\begin{abstract}
Coronavirus Disease 2019 (COVID-19) pandemic hit in 2020. This pandemic was causing changes in almost all sectors in our life, including education. Most of the education carried out in Indonesia uses the direct / face-to-face/ offline method between educators and students. The spread of COVID-19 is through direct contact or contact with air or surface containing the virus. The unevenness of perceptions, examinations, and existing protocols causes fear of face-to-face education. This research is a review of articles on COVID-19, health and education protocols during the COVID-19 pandemic. Public perceptions including educators, students and families about COVID-19 must be equalized to fight the pandemic together and welcome online education which is the safest option in education during pandemic.
\end{abstract}

\section{Keywords: Education, COVID-19, Pandemic}

\begin{abstract}
Abstrak
Tahun 2020 terjadi pandemi Coronavirus Disease 2019 (COVID19). Pandemi ini menyebabkan perubahan di hampir semua bidang, termasuk pendidikan. Pendidikan yang dilakukan di Indonesia banyak yang menggunakan cara langsung/tatap muka antara pendidik dan peserta didik. Penyebaran COVID-19 adalah melalui kontak langsung atau bersentuhan dengan barang-barang yang mengandung virus. Belum meratanya persepsi, pemeriksaan, dan protokol yang ada menyebabkan ketakutan untuk melakukan pendidikan secara tatap muka. Penelitian ini merupakan telaah artikel mengenai COVID-19, protokol kesehatan dan pendidikan selama masa pandemi COVID-19. Persepsi masyarakat termasuk pendidik, peserta didik dan keluarga mengenai COVID-19 harus disamakan untuk bersama melawan pandemi dan menyambut pendidikan secara daring yang merupakan pilihan paling aman dalam pendidikan pada masa pandemi.
\end{abstract}

\section{Kata Kunci : Pendidikan, COVID-19, pandemi}


Penyakit terbagi menjadi penyakit menular dan penyakit tidak menular. Penyakit menular merupakan penyakit yang dapat ditularkan dari satu makhluk hidup ke makhluk hidup yang lain. Coronavirus Disease 2019 (COVID19) merupakan penyakit menular yang dapat ditularkan dari manusia yang terinfeksi ke manusia yang lain.

Penularan COVID-19 dapat melalui cara langsung maupun tidak langsung. Cara penularan langsung adalah dengan cairan saluran pernafasan dari penderita (saat penderita batuk atau bersin) pada orang-orang yang berada di dekat penderita. Penderita dapat juga berkontak langsung saat bersalaman atau berpelukan dengan orang lain (Kamps and Hoffmann, 2020; Kementerian Kesehatan, 2020).

Cara penularan tidak langsung adalah melalui udara dan benda-benda yang dipegang oleh penderita. Virus Korona dapat hidup di udara selama 4 jam. Penderita yang batuk atau bersin dapat menerbangkan cairan pernafasan mereka di udara, kemudian bisa tetap di udara atau menempel di benda apa saja di dekatnya (Wicaksono and Nurfianti, 2020; World Health Organization, 2020).

Penderita yang tidak melakukan etika bersin dan batuk dengan baik, bisa saja menutup batuk atau bersinnya dengan tangan, kemudian sebelum mencuci tangan sudah menyentuh orang atau benda lain di dekatnya. Hal ini juga dapat menularkan COVID-19 pada orang yang sengaja atau tidak sengaja menyentuh tangan penderita atau barangbarang yang pernah disentuh oleh penderita.

Cara terbaik untuk mencegah penularan adalah dengan selalu melakukan penjarakan fisik, memakai masker dan menjaga kebersihan tangan dan diri. Ketiga hal tersebut harus dilakukan bersamaan, ketiga-tiganya sekaligus (Wicaksono and Nurfianti, 2020).

Pendidikan yang dilakukan di Indonesia dilakukan paling banyak secara langsung atau tatap muka. Cakupan pemeriksaan COVID-19 yang masih rendah membuat kita tidak pernah tahu siapa yang terpapar siapa yang tidak. Melakukan pengajaran di kelas berpotensi mengumpulkan orang banyak dalam satu ruangan dan tidak dapat berjauhan sehingga meningkatkan potensi penularan (Zhou, 2020).

Pendidikan di Indonesia dan dunia pun berubah untuk semua tingkatan dikarenakan pandemi COVID19. Penelitian ini menelaah dan memberikan rekomendasi pentingnya tetap melakukan pendidikan yang baik sembari tetap melakukan usaha untuk melawan pandemi COVID-19.

\section{METODE}

Penelitian ini merupakan penelitian telaah artikel yang berhubungan dengan COVID-19, pendidikan kedokteran dan pendidikan secara umum di Indonesia dan dunia selama pandemi.

Data yang digunakan adalah buku, jurnal, panduan, peraturan pemerintah, artikel, situs ilmiah, situs pemerintah baik nasional maupun internasional yang dikumpulkan sejak bulan Maret-Desember 2020.

\section{HASIL DAN PEMBAHASAN Hasil}

Jumlah kasus positif di dunia per tanggal 10 Januari 2021 adalah 88.383.771 dengan kematian sebanyak 1.919.126 jiwa (2,17 \%). Kasus positif di Indonesia adalah 836.718 dengan 
kematian sebanyak 24.343 jiwa $(2,91 \%)$ (COVID-19, 2021; Organization, 2021).

Angka ini diperkirakan akan terus meningkat karena mutasi virus, pandangan masyarakat mengenai pandemi, tambahan alat pemeriksaan dan kemajuan di bidang kedokteran dan kesehatan.

Virus korona merupakan virus yang sangat kecil yang harus diperiksa secara biologi molekuler. Virus korona ini dinamakan Severe Acute Respiratory Syndrome Coronavirus 2 (SARS-CoV-2) karena dapat membuat masalah pernafasan yang sangat berat, mirip dengan virus yang menyerang di tahun 2000, sehingga ada angka 2 di belakangnya (Duan, 2020; Gorbalenya et al., 2020).

Penyakit ini menular melalui cairan pernafasan yang pada bahasa medis disebut droplet. Droplet ini berisi cairan dari saluran pernafasan, dan pada kasus COVID-19, berisi virus dari penderita. Droplet ini bisa bertahan di udara dan pada permukaan beberapa benda selama 4 jam - berhari-hari (Klompas, Baker and Rhee, 2020; van Doremalen et al., 2020).

Cara mencegah penularan adalah dengan tidak melakukan kontak langsung dengan penderita, melakukan penjarakan fisik, memakai masker dan menjaga kebersihan tangan dan diri. Hal-hal inilah yang menjadi dasar untuk perubahan hidup sehari-hari di masa pandemi, termasuk dalam bidang pendidikan.

\section{Pembahasan}

Persepsi masyarakat yang berbeda, banyaknya informasi yang ada, ketakutan akan virus yang tidak terlihat, belum standarnya pemeriksaan dan alat tes membuat Indonesia bahkan dunia kebingungan.
Dunia pendidikan ikut terdampak pandemi ini dan harus menyesuaikan diri untuk tetap berjalan dan memberikan layanan dan hasil yang baik.

Pilihan yang ada adalah tetap memberikan layanan pendidikan untuk semua tingkat. Cara yang dilakukan berubah dari pembelajaran langsung/tatap muka/luring menjadi pembelajaran menggunakan teknologi informasi di dalam jaringan/daring (Anugrahana, 2020; Muhammad, 2020; Pendidikan Tinggi, 2020).

Pembelajaran di kelas secara langsung, tatap muka dan berdiskusi langsung tidak dapat dilakukan karena risiko penularan yang tinggi. Pembelajaran dilakukan dengan bantuan teknologi informasi dengan bantuan perangkat elektronik, jaringan internet dan aplikasi/program pendukung (Nizam, 2020).

Tantangan yang ada antara lain adalah budaya teknologi, jaringan internet, belum semua institusi pendidikan memiliki sistem pembelajaran daring, dan mahalnya sistem (Pendidikan Tinggi, 2020).

Budaya teknologi adalah kebiasaan penggunaan teknologi, dalam hal ini adalah teknologi informasi melalui gawai atau komputer yang dimiliki baik oleh tenaga pendidik, tenaga kependidikan, peserta didik dan keluarga peserta didik. Tidak semua tenaga pendidik atau tenaga kependidikan melek teknologi. Hal yang sama berlaku pula pada peserta didik dan keluarganya. Ada yang sudah terbiasa menggunakan gawai bersama program-programnya, ada yang bahkan tidak memiliki gawai yang memadai untuk melakukan proses pembelajaran(W. V. Indonesia, 2020; Latip, 2020).

Berbicara mengenai jaringan internet terdapat banyak cerita yang 
menyedihkan. Penyediaan jaringan internet di Indonesia belum merata. Penyedia layanan internet manapun memiliki titik-titik lemah, bahkan di wilayah perkotaan. Beberapa peserta didik harus pergi sejauh 1-3 jam dari tempat tinggal mereka ke pusat kota/kabupaten untuk mendapatkan sinyal. Belum lagi masalah geografis dan musim penghujan, yang membuat mereka harus benar-benar berjuang untuk mendapatkan akses internet (W. V. Indonesia, 2020; Nizam, 2020).

Pada masa revolusi industri keempat, semua hal harus didukung sistem informasi atau teknologi informasi yang kuat. Pandemi ini justru dapat membuat akselerasi penguatan sistim informasi di Indonesia pada seluruh tingkatan pendidikan. Pada sekolah atau institusi pendidikan yang belum siap mau tidak mau harus mempersiapkan segala hal dari sisi sumber daya manusia, fasilitas, dan sistem teknologi informasi (Karim, 2020; Muhammad, 2020).

Sistem teknologi informasi beserta perangkatnya relatif lebih mahal. Pada sistem ini diperlukan setidaknya gawai yang memadai, jaringan internet yang baik, sumber daya manusia yang mengerti teknologi informasi dengan baik, dan sistem informasi itu sendiri,

Gawai untuk tenaga pendidik, tenaga kependidikan, dan peserta didik di tingkat perguruan tinggi mungkin tidak menjadi masalah karena sekarang gawai yang memadai dengan harga yang terjangkau dapat diperoleh. Pada pendidikan dasar dan menengah akan timbul masalah seperti jumlah anggota keluarga, dimana semua membutuhkan gawai baik untuk bekerja, sekolah atau kuliah. Perebutan gawai dapat terjadi saat ada jadwal di waktu yang sama, mengingat saat ini banyak dilakukan belajar dari rumah untuk peserta didik dan bekerja dari rumah untuk tenaga pendidik, tenaga kependidikan dan orang tua/keluarga peserta didik (Aji, 2020; Indrawati, 2020).

Pada banyak perguruan tinggi sudah melakukan kebijakan penurunan Uang Kuliah Tunggal dalam rangka bantuan keringanan biaya pendidikan karena pandemi yang menyebabkan penurunan kemampuan ekonomi keluarga peserta didik dan untuk membantu penyediaan gawai yang memadai. Pada salah satu institusi pendidikan bahkan diberikan bantuan gawai kepada peserta didik yang memang tidak mampu.

Kemahalan kedua adalah biaya pulsa dan internet untuk memenuhi pembelajaran daring. Kuota untuk mendapatkan besar data tertentu dalam satu satuan waktu memang berbeda-beda. Pada materi yang menggunakan tulisan/ gambar saja jelas membutuhkan kuota kecil. Materi yang menggunakan suara, video akan membutuhkan kuota yang lebih besar dan berbanding lurus dengan durasi materi tersebut. Semakin lama materi dan semakin baik kualitas audiovisual akan menambah besar kuota yang diperlukan.

Hal ini sudah ditanggapi dengan baik oleh pemerintah, sekolah, perguruan tinggi dengan bekerja sama dengan Kementerian Komunikasi dan Informasi dan penyedia layanan seluler dalam bentuk pemberian kuota gratis untuk tenaga pendidik, tenaga kependidikan dan peserta didik. Layanan ini dapat digunakan sepanjang pandemi dan dapat diakses dengan aplikasi/program tertentu. Pemerintah juga mulai menambah dan memperbaiki jumlah titik-titik yang menyediakan layanan pulsa dan internrt di daerah-daerah yang selama ini belum mendapatkan layanan tersebut (Nizam, 2020; Sumantyo, 2020). 
Sistem teknologi informasi yang ada juga harus diperkuat untuk dapat diisi dengan materi-materi yang baik dan berkualitas, dapat menjangkau area yang luas dan tidak bermasalah dalam hal energi listrik.

Pada akhirnya, sumber daya manusia yang baik, paham dan menguasai teknologi informasi merupakan hal yang sangat penting dalam mengelola dan mempertahankan sistem teknologi informasi dengan baik karena apalah artinya gawai, jaringan dan sistem yang mumpuni tetapi kita tidak memiliki orang yang dapat menjaga dan mengelolanya dengan baik.

Pelatihan mengenai sistem pembelajaran, teknologi informasi dan COVID-19 harus selalu dilakukan. Perbaikan dan peningkatan gawai serta perangkat sistem harus dilakukan secara berkala untuk menjaga kebaruan dan perkembangan teknologi informasi di bidang pendidikan.

Terdapat beberapa peraturan baik di tingkat pusat maupun daerah yang mengatur mengenai tata cara bekerja, belajar dan mengajar saat pandemi. Keputusan untuk melakukan belajar di rumah, mengajar di rumah dan bekerja di rumah memperlihatkan bahwa itulah hal yang paling aman untuk dilakukan pada dunia pendidikan di masa pandemi (Pendidikan dan Kebudayaan, 2020; Pontianak, 2020; Tanjungpura, 2020).

Ada beberapa materi yang memang tidak bisa dilakukan secara daring seperti praktikum dan keahlian khusus. Materi yang harus dilakukan secara langsung/luring ini merupakan pilihan terakhir dalam pendidikan di masa pandemi ini. Hal ini dapat dilakukan dengan memenuhi protokol kesehatan (Muhammad, 2020; Nizam, 2020; Pendidikan Tinggi, 2020).
Beberapa panduan untuk pendidikan luring di masa pandemi merekomendasikan hal-hal berikut ini harus dipenuhi dalam pencegahan COVID-19 (Dalam Negeri, 2020; Ketenagakerjaan, 2020; Organization, 2020; Zhou, 2020).

Intinya adalah sterilisasi di setiap sektor. Gedung tempat proses pendidikan harus disemprot disinfektan 4 jam sebelum dipergunakan. Gedung, lorong, halaman, dan alat-alat yang ada di dalam ruangan juga harus disemprot. Setelah selesai melakukan kegiatan, disemprot kembali dan baru boleh digunakan 4 jam kemudian.

Tempat pendidikan harus menyediakan alat pengukur suhu, air bersih mengalir, sabun, tisu dan tempat sampah yang mudah diakses oleh setiap orang yang datang.

Seluruh orang yang datang ke tempat pendidikan harus menggunakan masker, disarankan masker bedah atau masker kain tiga lapis. Penjarakan tetap harus dilakukan selama berada di tempat pendidikan dengan jarak antar orang 2 meter.

Hal terakhir adalah hal yang paling sulit yaitu semua yang datang harus bebas COVID-19 dengan bukti hasil pemeriksaan apusan Polymerase Chain Reaction $(P C R)$ negatif. Tenaga pendidik, tenaga kependidikan, peserta didik atau keluarga yang akan dating ke tempat pendidikan harus tidak menderita COVID-19.

Semua orang harus menjaga kebersihan dan kesehatan dirinya dengan mematuhi protokol kesehatan untuk COVID-19. Harus semua orang steril (dalam hal ini bebas/negatif COVID-19) baru dapat bertemu, di ruangan atau tempat yang steril, dengan protokol kesehatan yang dilakukan ketat sepanjang waktu. Pertimbangan inilah 
yang menyebabkan sulitnya melakukan pembelajaran secara luring di masa pandemi.

Beberapa penelitian di beberapa negara memperlihatkan peningkatan kasus tinggi langsung paska pembukaan kembali pembelajaran luring pada satuan pendidikan yang menunjukkan bahwa jika tidak dilakukan dengan baik secara sepenuhnya suatu protokol kesehatan, hasilnya adalah klaster atau tempat terjadinya kasus positif di tempat tertentu (Christakis, 2020; Esposito and Principi, 2020).

Ikatan Dokter Anak Indonesia (IDAI) memberikan rekomendasi untuk tetap melakukan pembelajaran daring selama pandemi ini (I. D. A. Indonesia, 2020). Rekomendasi dibuat untuk SD dan SMP (karena di usia anak) tetapi dapat juga dipergunakan untuk SMA dan perguruan tinggi karena yang menjadi fokus adalah kontak dengan orang lain dan bertemu beberapa orang dalam waktu yang lama. Hal ini bisa saja terjadi pada anak, remaja, dewasa dan orang tua sehingga berpotensi menularkan COVID-19.

\section{SIMPULAN DAN SARAN \\ Simpulan}

1. Pandemi COVID-19 sudah terjadi dan masih berlangsung

2. Cara yang paling efektif untuk mencegah penularan COVID-19 adalah dengan selalu melakukan penjarakan fisik, memakai masker dan menjaga kebersihan tangan dan diri secara bersamaan.

3. Pendidikan yang paling aman pada masa pandemi adalah pendidikan secara daring.
4. Pada kasus tertentu dimana tidak memungkinkan dilakukan pendidikan secara daring, maka pendidikan secara luring dapat dilakukan dengan memenuhi protokol kesehatan yang baik.

\section{Saran}

1. Diperlukan pelatihan khusus mengenai COVID-19 pada tenaga pendidik, tenaga kependidikan, peserta didik dan keluarga untuk menyamakan persepsi mengenai pandemi yang sedang berlangsung.

2. Diperlukan pelatihan khusus mengenai pengajaran daring untuk tenaga pendidik dan tenaga kependidikan dalam rangka penguatan sistem pembelajaran di masa pandemi.

3. Diperlukan pertemuan berkala antara pihak institusi pendidikan dan peserta didik dan keluarga untuk tetap dapat saling berkomunikasi dengan baik dan menjalankan pendidikan dengan baik.

\section{DAFTAR RUJUKAN}

Aji，R. H. S. (2020) 'Dampak Covid-19 pada Pendidikan di Indonesia: Sekolah, Keterampilan, dan Proses Pembelajaran', SALAM: Jurnal Sosial dan Budaya Syar-i, 7(5). doi: 10.15408/sjsbs.v7i5.15314.

Anugrahana, A. (2020) 'Hambatan, Solusi dan Harapan: Pembelajaran Daring selama Masa Pandemi Covid-19 oleh Guru Sekolah Dasar', Scholaria: Jurnal Pendidikan 
dan Kebudayaan, 10(3), pp. 282-289. doi: 10.24246/j.js.2020.v10.i3.p282-289.

Christakis, D. A. (2020) 'School Reopening-The Pandemic Issue That is not Getting its Due', JAMA Pediatrics, (May), p. E1. doi: 10.1001/jamapediatrics.2020.2068.

COVID-19, G. T. P. P. (2021) 'Data Sebaran Tanggal 11 Januari 2021'. Jakarta: Gugus Tugas Percepatan Penanganan COVID-19. Available at: covid19.go.id/.

Dalam Negeri, K. (2020) Pedoman Tatatanan Normal Baru Produktif dan Aman Corona Virus Disease 2019 bagi Aparatur Sipil Negara di Lingkungan Kementerian Dalam Negeri dan Pemerintah Daerah, Keputusan Menteri Dalam Negeri Nomor 440 - 830 Tahun 2020. Indonesia: Kementerian Dalam Negeri Republik Indonesia.

van Doremalen, N. et al. (2020) 'Aerosol and Surface Stability of SARSCoV-2 as Compared with SARS-CoV-1', The New England Journal of Medicine, (March), pp. 1-3. doi: 10.1056/NEJMc2004973.

Duan, G. (2020) 'Virology, Epidemiology, Pathogenesis, and Control of COVID-19', viruses, 12(372), pp. 117. doi: 10.3390/v12040372.

Esposito, S. and Principi, N. (2020) 'School Closure during the Coronavirus Disease 2019 Pandemic', JAMA Pediatrics, (May), pp. E1-E2. doi: 10.1001/jamapediatrics.2020.1892.

Gorbalenya, A. E. et al. (2020) 'The species Severe acute respiratory syndrome-related coronavirus: classifying 2019-nCoV and naming it SARS-CoV-2', Nature Microbiology, 5(4), pp. 536-544. doi: 10.1038/s41564020-0695-z.

Indonesia, I. D. A. (2020) Pendapat IDAI mengenai Rencana
Transisi Pembelajaran Tatap Muka. Indonesia: Pengurus Pusat Ikatan Dokter Anak Indonesia. Available at: www.idai.or.id.

Indonesia, W. V. (2020) Pandemi COVID-19 dan Pengaruhnya terhadap Anak Indonesia. Tangerang Selatan. Available at: www.wahanavisi.org.

Indrawati, B. (2020) 'Tantangan dan Peluang Pendidikan Tinggi Dalam Masa dan Pasca Pandemi Covid-19', Jurnal Kajian Ilmiah, 1(1), pp. 39-48. doi: 10.31599/jki.v1i1.261.

Kamps, B. S. and Hoffmann, C. (2020) COVID Reference. 1st edn. Edited by R. Camp. Hamburg: Steinhauser Verlag.

Karim, B. A. (2020) 'Pendidikan Perguruan Tinggi Era 4.0 Dalam Pandemi Covid-19 (Refleksi Sosiologis)', Education and Learning Journal, 1(2), pp. 102-112. doi: 10.33096/eljour.v1i2.54.

Kementerian Kesehatan (2020) Pedoman Pencegahan dan Pengendalian Coronavirus Disease (COVID19) Revisi ke-4. Jakarta: Kementerian Kesehatan Republik Indonesia.

Ketenagakerjaan, K. (2020) Pedoman Keselamatan dan Kesehatan Kerja pada Masa Pandemi COVID-19. Indonesia: Kementerian Ketenagakerjaan Republik Indonesia.

Klompas, M., Baker, M. A. and Rhee, C. (2020) 'Airborne Transmission of SARS-CoV-2', Journal of American Medical Association, (July), pp. E1-2. doi: 10.1001/jama.2020.12458.

Latip, A. (2020) 'Peran Literasi Teknologi Informasi Dan Komunikasi Pada Pembelajaran Jarak Jauh Di Masa Pandemi Covid-19', EduTeach: Jurnal Edukasi dan Teknologi Pembelajaran, 1(2), pp. 108-116. doi: 10.37859/eduteach.v1i2.1956.

Muhammad, $\quad \mathrm{H}$.

(2020) 
'Menyiapkan Pembelajaran di Masa Pandemi: Tantangan dan Peluang', Kemendikbud. Jakarta: Kementerian Pendidikan dan Kebudayaan, p. 22.

Nizam (2020) 'Paparan

Kebijakan Pendidikan Tinggi Masa Pandemi Covid-19', Paparan Kebijakan Pendidikan Tinggi Masa Pandemi Covid19. Jakarta: Kementerian Pendidikan dan Kebudayaan.

Organization, W. H. (2020) COVID-19 Strategy Update, Covid-19 Strategy Update. Geneva: World Health Organization. Available

WWW.who.int/emergencies/en.

Organization, W. H. (2021) 'WHO Coronavirus Disease Dashboard'. Geneva: World Health Organization. Available at: covid19.who.int/.

Pendidikan dan Kebudayaan, D.

(2020) Surat Dinas Dikbud Kalbar tentang Perpanjangan Masa Belajar di Rumah. Indonesia: Dinas Pendidikan dan Kebudayaan Provinsi Kalimantan Barat.

Pendidikan Tinggi, D. J. (2020)

Buku Pendidikan Tinggi di Masa Pandemi COVID-19. Jakarta: Kementerian Pendidikan dan Kebudayaan. Available at: www.dikti.kemdikbud.go.id.

Pontianak, W. (2020) Surat

Edaran Walikota Pontianak untuk
Pendidikan.pdf. Indonesia: Pemerintah Kota Pontianak.

Sumantyo, F. D. S. (2020) 'Pendidikan Tinggi di Masa dan Pasca Covid-19', Jurnal Kajian Ilmiah, 1(1), pp. 81-92. doi: 10.31599/jki.v1i1.266.

Tanjungpura, U. (2020) Surat Edaran tentang Peningkatan Kewaspadaan dan Pencegahan Penyebaran Infeksi COVID-19 di Lingkungan Universitas Tanjungpura, SE Rektor Untan. Indonesia: Universitas Tanjungpura. Available at: www.untan.ac.id.

Wicaksono, A. and Nurfianti, A. (2020) Penyakit Virus Korona-19. Pontianak: IAIN Pontianak Press.

World Health Organization (2020) 'Pencegahan dan Pengendalian Infeksi ( PPI ) untuk Novel Coronavirus ( COVID-19 )'. Geneva: World Health Organization. Available at: https://www.who.int.

Zhou, W. (2020) The Coronavirus Prevention Handbook. New York: Skyhorse Publishing. Available at: www.skyhorsepublishing.com. 